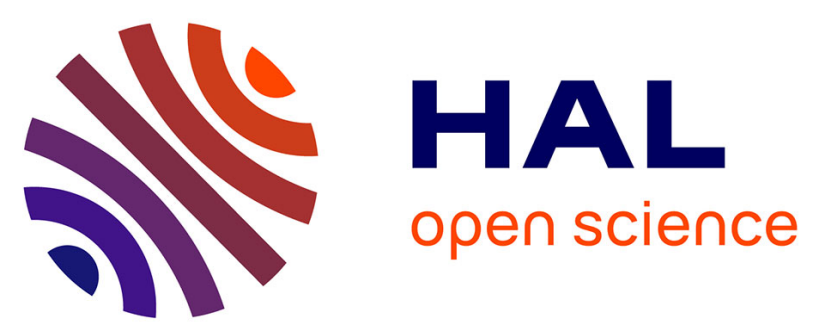

\title{
FIRST PALEOMAGNETIC RESULTS FROM NEOGENE FORMATIONS IN EVIA, SKYROS AND THE VOLOS REGION AND THE DEFORMATION OF CENTRAL AEGEA
}

Catherine Kissel, Carlo Laj, Alain Mazaud

\section{To cite this version:}

Catherine Kissel, Carlo Laj, Alain Mazaud. FIRST PALEOMAGNETIC RESULTS FROM NEOGENE FORMATIONS IN EVIA, SKYROS AND THE VOLOS REGION AND THE DEFORMATION OF CENTRAL AEGEA. Geophysical Research Letters, 1986, 13 (13), pp.1446-1449. 10.1029/GL013i013p01446 . hal-03540855

\section{HAL Id: hal-03540855 \\ https://hal.science/hal-03540855}

Submitted on 24 Jan 2022

HAL is a multi-disciplinary open access archive for the deposit and dissemination of scientific research documents, whether they are published or not. The documents may come from teaching and research institutions in France or abroad, or from public or private research centers.
L'archive ouverte pluridisciplinaire HAL, est destinée au dépôt et à la diffusion de documents scientifiques de niveau recherche, publiés ou non, émanant des établissements d'enseignement et de recherche français ou étrangers, des laboratoires publics ou privés. 
FIRST PALEOMAGNETIC RESULTS FROM NEOGE NE FORMATIONS IN EVIA, SKYROS AND THE VOLOS REGION AND THE DEFORMATION OF CENTRAL AEGEA.

Catherine Kissel, Carlo Laj and Alain Mazaud.

Centre des Faibles Radioactivités, Laboratoire mixte CNRS/CEA, Domaine du CNRS, 91190 Gif-sur-Yvette, France.

Abstract. Paleomagnetic results from Neogene volcanic and sedimentary formations in central Aegea indicate that Evia and Skyros have undergone $\mathrm{a} 48^{\circ}$ and $26^{\circ}$ clockwise rotation respectively. The Volos region does not show any significant rotation in the last $3 \mathrm{Ma}$. The rotation of Evia is about twice as large as the one measured from coeval formations in the external Hellenic arc. The results are interpreted in terms of a published model of distributed deformation by faulting, which also provides an explanation for the significant differential rotation of Evia and Skyros.

\section{Int roduction}

In the last few years different authors have considered the problem of the deformation of Aegea and have suggested models for the geodynamical evolution of this area. Some of these mode1s (Brunn, 1976; Tapponnier, 1977) assume that the deformation is entirely related to the main Tertiary Alpine phase and is thus completed before the neotectonic period. However, many recent tectonic, paleomagnetic and geophysical studies have led to the recognition of the extreme mobility of the Aegean lithosphere (McKenzie, 1978; Le Pichon and Angelier, 1979; Mercler et al., 1979; Laj et al., 1982; Horner and Freeman, 1983; Kondopoulou et Lauer, 1984; Kissel et al., 1985; $1986 \mathrm{a}, \mathrm{b})$. So that it is now widely accepted that very large deformations have occurred in Aegea in the last few million years during the neotectonic period.

Le Pichon and Angelier (1979) for instance, consider that major neotectonic movements occurred in the last $13 \mathrm{Ma}$. According to these authors this movement is at first approximation $a 30^{\circ}$ clockwise rotation of a semi-rigid plate about a pole situated near $40^{\circ} \mathrm{N} ; 18^{\circ} \mathrm{E}$ in the southern Adriatic Sea. A large back-arc distension, up to about $70 \%$, is superimposed to this rotation locally modifying its value which is maximum in the northwestern region and progressively decreases eastward to attain zero near the Anatolian coast. Aegea cannot thus be considered as a rigid plate. The extent of the deformation has led Mercier (1977) and Mercier et al., (1979) to consider Aegea as the plastically deformed edge of the Eurasiatic plate, with movement occurring along slip lines as suggested by Tapponnier (1977).

More recently McKenzie and Jackson (1983) have proposed a model for central Aegea in which the right-handed NE-SW strike-slip motion along the North-Aegean trough is taken up on a number of several normal faults striking ESE with a lefthanded strike-slip component. This system forms a

Copyright 1986 by the American Geophysical Union.

Paper number $6 \mathrm{~L} 6377$.

$0094-8276 / 86 / 006 \mathrm{~L}-6377 \$ 03.00$ shear zone connecting the North-Aegean trough to the Hellenic arc. The rigid blocks bounded by the normal faults can be shown to undergo surprisingly large clockwise rotations when geologically reasonable slip rates related to the SW expansion of Aegea are used in the model.

In this paper we report paleomagnetic results obtained from upper Miocene to upper Pliocene formations in central Aegea which are discussed within the framework of the above models.

\section{Geological Setting and Sampling}

Since at least the upper Miocene, central Aegea has been submitted to a large scale extensional regime only occasionally interrupted by compressive events in the lower Pliocene and lower Pleistocene periods (Mercier et al., 1979; Le Pichon and Angelier, 1979). This has resulted in large-scale normal faulting grabens and troughs. The neotectonic period is also characterized in this region by a dextral strike-slip motion along the north Anatolian fault the western termination of which is located north of Evia. In northern and central Aegea widespread calc-alkaline activity occurred, belonging to two different phases of volcanic activity of Oligo-Miocene and Plio-Quaternary age separated by a period of quiescence of several million years (Bellon et al., 1979; Fytikas et al., 1984). In addition to these calc-alkaline products, small volumes of lava with variable petrogenetic character were emitted over all central Aegea. Sedimentary formations are also present and essentially constituted by continental (fluvio-lacustrine) and brackish 1 imestones and marls which indicate the quasi-definitive emersion of these regions.

Sites were sampled in volcanic and sedimentary formations in the 1slands of central Aegea (Evia, Skyros, Alonissos) and from the Volos region. The geographical location of these sites is indicated in the schematic map of Figure 1.

Near the village of Glifa in the Volos region four sites (Vo 235 to Vo 238) were sampled in lava flows of basaltic-andesitic affinity, i.e. not belonging to the calc-alkaline phases, $\mathrm{K} / \mathrm{Ar}$ dated at 3.0 Ma (Fytikas et a1., 1984). The structural position of these flows and their general aspect indicate that they have not undergone any significant tectonic tilt.

In the island of Alonissos in the northern Sporades three sites were sampled in upper M10cene micritic limestones from the small Cenozoic basin in the southeastern part of the island.

In Skyros the volcanic products are located in the central and southeastern parts of the island but in this last location heavy weathering precludes any paleomagnetic study. We have sampled 5 sites in the calc-alkaline lava near the village of Bares in the central part. The products, the $\mathrm{K} / \mathrm{Ar}$ age of which is $15.0 \pm 0.7$ 


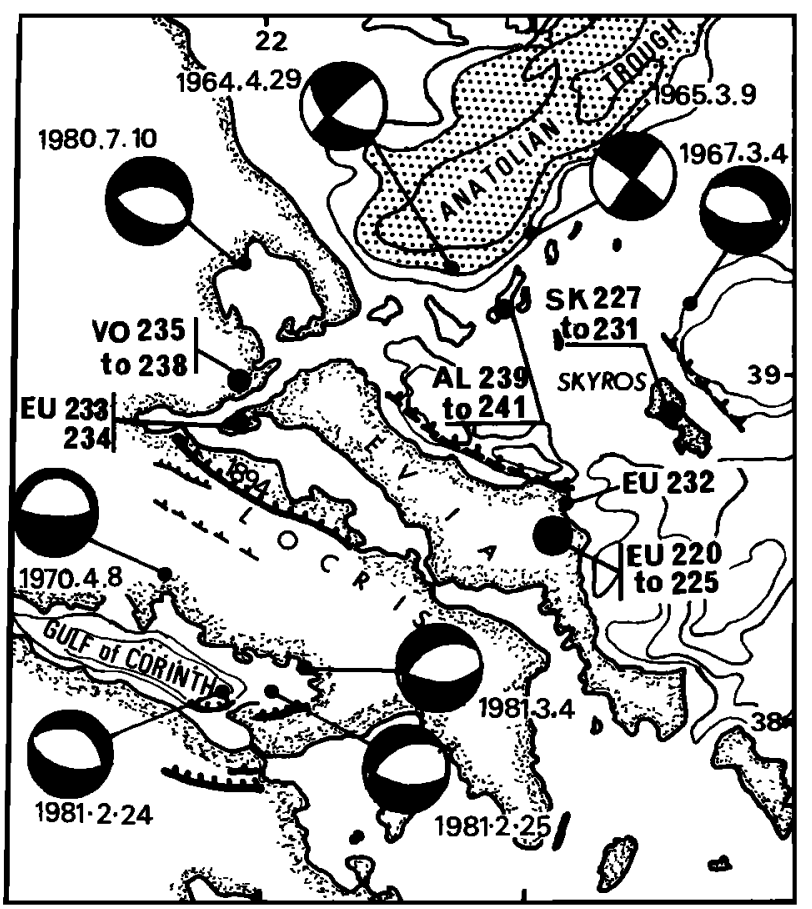

Fig. 1. Schematic map showing, according to McKenzie and Jackson (1983), the geometry of normal faulting zone in central Aegea. Fault plane solutions are lower-hemisphere projections with compressional quadrants blacks. The location of the paleomagnetic sites in the Volos region, Alonissos, Evia and Skyros is indicated.

$\mathrm{Ma}$, range between andesites and dacites (Fytikas et a1., 1984) and they have been int ruded into the Mesozoic carbonatic series which appears horizontal in this region.

In Evia no suitable sites could be found in the southern part of the island where the formations are metamorphosed. In the northern part, the neogene lacustrine basins are of ten covered by thick vegetation or weathered. Only a few outcrops suitable for a paleomagnetic study could be found in spite of careful search. Six sites were sampled in the volcanic complex of lava flows and domes located south of Kymi (K/Ar age: $13 \pm 0.4 \mathrm{Ma}$; Fytikas et al., 1984). These volcanic products of calc-alkaline affinity with high $\mathrm{K}_{2} \mathrm{O}$ content overly the lacustrine marly limestones of the Kymi basin of Aquitanian to Pontian age ( $F$. Lemeille, Thèse, 1977). The bedding plane of these formations, accurately measurable at different localities, has a constant attitude over the entire basin and has thus been used for restoring the volcanic formations to their paleohorizontal position. only one suitable sedimentary site (EU 232) could be localized in this region, just south of Kymi. In the north of the island, two sites (EU 233, 234) were sampled in lacustrine limestones near the village of Lichades. This formation, according to Philip (H. Philip, Thèse, 1974), is overlain by the pretiglian (Upper Pliocene) basal level of the 'Yaltra series'. However, the Ka1lidromon sedimentary series which is the lateral equivalent of the Lichades sediments is dated about lower Quaternary (T. Rondogianni, Thèse, 1984). Although certain1y ill dated, these formations are of upper Pliocene-lower Quaternary age.
Results

Alternating field and thermal demagnetization used on pilot samples isolated the same stable paleomagnetic direction but thermal treatment was preferred because the results obtained by this method were systematically more consistent. Measurements we re done using a Spinner magnetometer for the volcanic samples and a LETI 3-axes cryogenic magnetometer for the sedimentary ones. The magnetic susceptibility of at least two samples per site was measured at each step of demagnetization using a susceptibility bridge. No significant changes have been observed between room temperature and $550^{\circ} \mathrm{C}$ indicating that the magnetic minerals are not seriously affected by the thermal treatment. IRM acquisition experiments show that magnetite is the main magnetic carrier, with a small contribution of a higher coercitivity mineral. The direction of the stable magnetization could be precisely determined for all the samples by drawing a straight line through the last 5-6 points (Figure 2).

\section{Stable Paleomagnetic Directions}

All the mean stable paleomagnetic direction obtained for each site are reported in Table $I$. No result have been obtained from Alonissos because the NRM is so weak $\left(<10^{-4} \mathrm{~A} / \mathrm{m}\right)$ that no sample could be measured with the necessary accuracy even with the cryogenic magnetometer.

The four sites studied in the Volos region yield tightly grouped results with reverse directions and declinations pointing perfectly south.

In Sky ros the within-site scatter is very small but, while 4 sites yield tightly grouped di rections, the mean direction obtained from site SK 231 is different from the others. A possible explanation could be the presence of a local landslide (this site is sampled on the flank of a hill) which could be easily unoticed because of the rather thick vegetation.

In Evia the well grouped di rections from the six volcanic sites and the sedimentary site in Kymi indicate that a large clockwise rotation of about $48^{\circ}$ has affected this region. The sedimentary sites from northern Evia also have a stable reverse component of magnetization whose direction is the same as that of the older sites near Kymi.

\section{Discussion}

The results reported above indicate that the Volos region has not undergone any significant

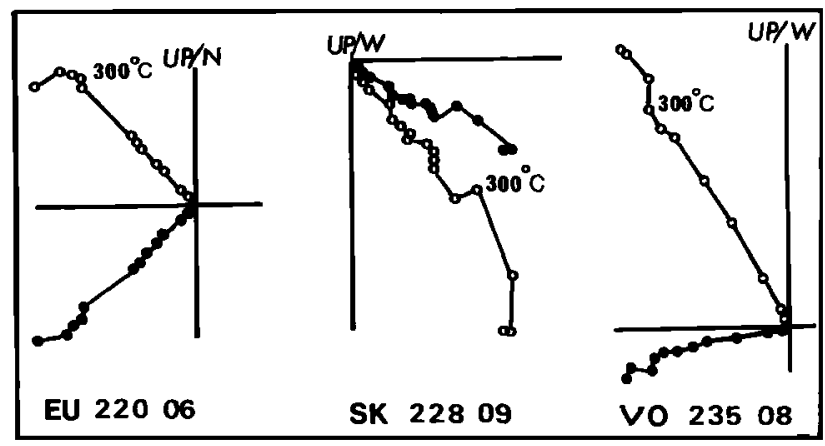

Fig. 2. Typical demagnetization diagrams. Full circles: horizontal projection; open circles: vertical projection. 
TABLE 1. Paleomagnetic Directions from 18 Stable Sites in Central Aegea

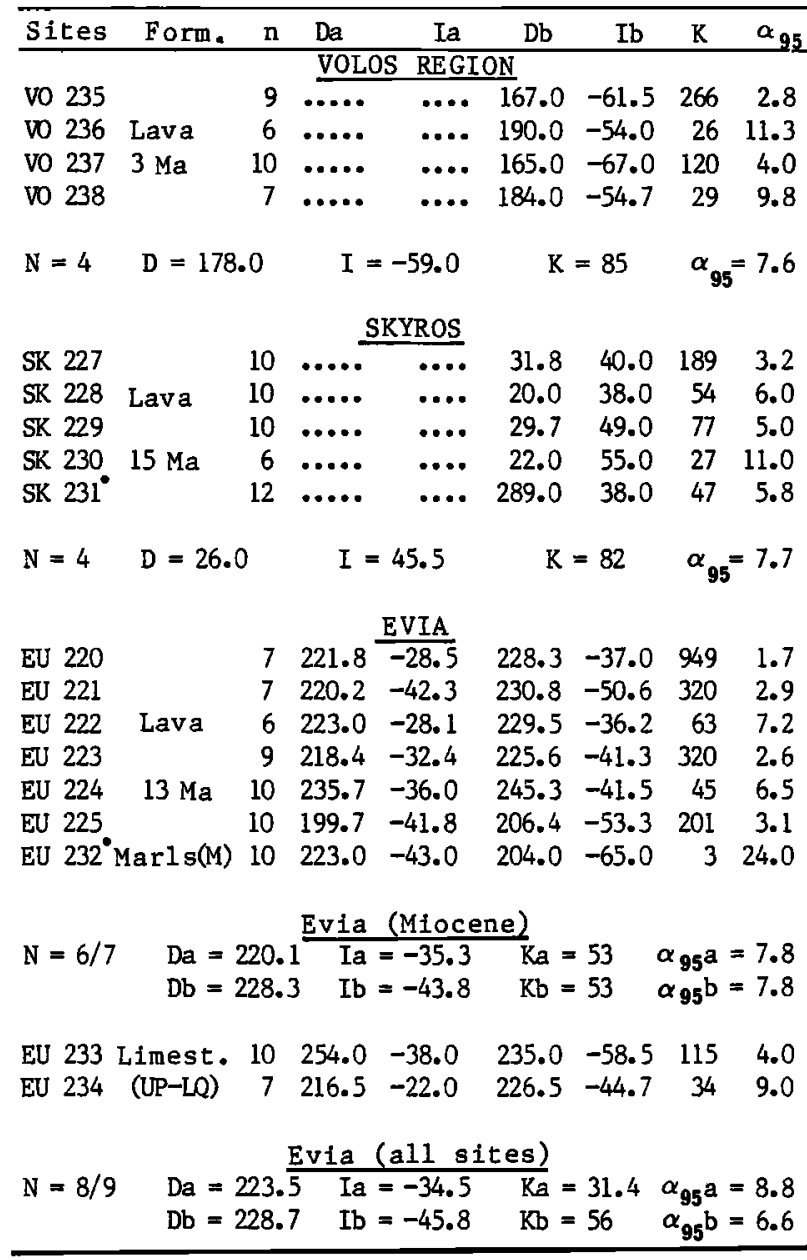

- : site rejected (see text). Results are reported before ( $\mathrm{Da}, \mathrm{Ia}$ ) and after ( $\mathrm{Db}, \mathrm{Ib}$ ) bedding correction was applied. Results from sites for which the bedding plane is horizontal are reported only in (Db, Ib). (M): Miocene; (UP-LQ): upper P1iocene-lower Quaternary.

rotation in the last three million years. Evia and Skyros on the contrary have undergone clockwise rotation of about $48^{\circ}$ and $26^{\circ}$ respectively since at most Upper Miocene.

Paleomagnetic studies have recently documented a $45^{\circ}$ clockwise rotation in northwestern Greece (Horner and Freeman, 1983; Kissel et al., 1985). This rotation has occurred in two phases of comparable amplitude, one during the middle Miocene and one during the Pliocene and Quaternary. The most recent of the two phases has been precisely time bracketed: its onset coincides with the main compressive phase of upper Miocene -lower Pliocene age ( $5 \mathrm{Ma}$ ) and it has since proceeded at a constant rate of $5^{\circ} / \mathrm{Ma}$ (Laj et al., 1982). On the contrary the exact timing of the former rotation is rather 111 known. However, it was certainly completed at $12 \mathrm{Ma}$, because a period of at least $7 \mathrm{Ma}$, between 12 and $5 \mathrm{Ma}$, during which no significant rotation occurred has also been documented ( $L a j$ et al., 1982). This period is thus coeval with the epoch of quiescience separating the two phases of calcalkaline volcanic activity, so that it seems un- realistic to think that major geodynamical movements might have occurred in Central Aegea during a period of overall very reduced or null tectonic or volcanic activity. A much more reasonable hypothesis is that the large rotations documented in Evia and Skyros have occurred synchronously with one or the other of the two phases of rotation documented in Northwestern Greece.

The age of the volcanic formation in Skyros does not allow to attribute the rotation of this island to one or the other of the two phases. The volcanic products in Evia on the contrary mark the end of the oligo-miocene phase (Fytikas et al., 1984) and the sedimentary formations are much younger. Although we are well aware that our data are scarce, we suggest that the rotations observed in Central Aegea are more 1ikely related to the Plio-Plelstocene rotation of the external zone than to the middle Miocene one. If correct, this suggestion implies that, during the Pliocene, coeval rotational movements were of greater amplitude in central Aegea than in northwestern Greece. The present data thus do not sustain a previous analysis in terms of a regular eastward decrease of the rotational deformation in this region, made when the results from Evia were not all available (Kissel et al., 1986a). In the same way, none of the models assuming a continuous change of the rotational deformation is bound to yleld a sultable description of central Aegea, where the damping of the right-handed strike-slip movement along the north Anatolian fault introduces a marked discontinuity. On the contrary, a progressive change in the rotational deformation probably occurs in northern Aegea (Kondopoulou and Lauer, 1984; Kondopoulou and Westphal, 1986; Kissel et al., $1986 \mathrm{a}, \mathrm{b})$.

For central Aegea, the only model which specifically considers the damping of the movement along the north Anatolian fault is the one suggested by McKenzie and Jackson (1983) in which this region is considered as a shear zone formed by fault-limited rotating blocks, between the north Aegean trough and the Hellenic arc. Assuming a slip rate of $5 \mathrm{~cm} /$ year across a shear zone $50 \mathrm{~km}$ wide, these authors have calculated an instantaneous rotation rate of $40^{\circ}$ to $20^{\circ}$ per million years depending on whether the rotating blocks are pinned to the boundaries of the shear zone or are floating. Geological studies have not evidenced major changes in the tectonic pattern of central Aegea in the last few million years so that it is reasonable to assume that the shear zone has existed during this time. Taking a width of $90 \mathrm{~km}$, which seems to us more realistic than $50 \mathrm{~km}$, then the observed rotation of $48^{\circ}$ implies a very reasonable mean slip rate of the order of 1.5 to $2.5 \mathrm{~cm} / \mathrm{y}$ over the last $5 \mathrm{Ma}$.

The Volos region, situated north of the shear zone, is supposed to be fixed in the mode1. This assumption is in agreement with the paleomagnetic results. Moreover, the model yields a possible explanation for the significantly different rotations of Skyros and Evia which are only $30 \mathrm{~km}$ away from each other. Indeed, noting that the rotation of Skyros is closely one half that of Evia, this difference could be explained assuming that skyros belongs to a block more loosely attached to the borders of the shear zone or entirely floating.

It must, however, be noted that if the deformation has to be approximated by the 
movement of perfectly rigid blocks separated by faults which move both normal and parallel to their strike, a definite angular relationship must exist between the strike of the faults, the trend of the zone and the velocity gradient. For a given trend and velocity only a particular orientation of the faults will fulfil this condition: this is the present day situation in Central Aegea (McKenzie and Jackson, 1983). This angular relationship can however be satisfied only instantaneously, so that if the fault limited blocks have to be rotated through a finite angle either the trend of the zone or the velocity gradient must change, or else one has to consider that deformation of the blocks also occurs. These points are difficult to check because the subnerged character of Central Aegea does not allow to extend the paleomagnetic sampling. In the same way a denser sampling is needed in Northern Evia to check whether the rather large rotations of the young sedimentary formation could be at least partially due to local rotation linked to deformation at the boundaries of the shear zone. Nevertheless, and in spite of their uncompleteness the paleomagnetic data indicate the existence in central Aegea of large rotations for which the model of McKenzie and Jackson provides a convenient explanation.

Aknowledgements, We wish to thank J. Jackson and J. L. Mercier for helpful discussions, $D$. Decini and $S$. Guftton for their help in the field. The Director of the IGME at Athens kindly provided the necessary permits. The financial support was given by the CEA, the CNRS and the INSU-ATP Sismogénèse, Plis et Failles: Mécanique de 1a lithosphère.

CFR Contribution 804.

\section{References}

Bellon, H., J. J. Jarrige, and D. Sorel, Les activités magmatiques égéennes de l'oligocène à nos jours et leurs cadres géodynamiques. Données nouvelles et synthèse, Rev. Géol. Dyn. Géogr. Phys., 21, 41-55, 1979.

Brunn, J. H., L'arc concave zagro-taurique et les arcs convexes taurique et égéen: collision et arcs induits, Bull. Soc. Geol. $\mathrm{Fr}_{p}, 18$, 553-567, 1976.

Fytikas, M., F. Innocenti, P. Manetti, R. Mazzuoli, A. Peccerillo, and L. Villari, Tertiary to Quaternary evolution of the volcanism in the Aegean region, in The geological evolution of the Eastern Mediterranean, edited by J.E. Dixon and A.H.F. Robertson, Spec. Publ. Geol. Soc. London, 17, $687-699,1984$.

Horner, F., and R. Freeman, Paleomagnetic evidence from pelagic limestones for clockwise rotation of the Ionian Zone, Western Greece, Tectonophysics, 98, 11-27, 1983.

Kissel, C., C. Laj, and C. Muller, Tertiary geodynamical evolution of Northwestern Greece: palaeomagnetic results, Earth and Planet. Sci. Lett., 72, 190-204, 1985.

Kissel, C., C. Laj, A. Poisson, Y. Savaşçin, K. Simeakis, and J. L. Mercler, Paleomagnetic evidence for Neogene rotational deformations in the Aegean domain, Tectonics, 5, 5, 783-796, 1986a.

Kissel, C., D. Kondopoulou, C. Laj, and P. Papadopoulos, New paleomagnetic data from oligocene formations in Northern Aegea, Geophys. Res. Lett., in press, 1986b.

Kondopoulou, D. and J. P. Lauer, Paleomagnetic data from Tertiary units of the north Aegean zone, in The Geological Evolution of the eastern Mediterranean, edited by J.E. Dixon and A. H. F. Robertson, Spec. Publ. Geol. Soc. London, 17, 681-686, 1984 .

Kondopoulou, D., and M. Westphal, Paleomagnetism of the Tertiary intrusives from Chalkidiki (Northern Greece), J. Geophysics, 59, 62-66, 1986.

Laj, C., M. Jamet, D. Sorel, and J. P. Valente, First paleomagnetic results from Mio-P1iocene series of the Hellenic sedimentary arc, Tectonophysics, 86, 45-67, 1982.

Le Pichon, $X_{.}$, and $\mathrm{J}$. Angelier, The Hellenic Arc and Trench system: a key to the neotectonic evolution of the Eastern Mediterranean Area, Tectonophysics, 60, 1-42, 1979.

McKenzie, D., Active tectonics of the Alpine-Himalayan belt: the Aegean Sea and surrounding regions (tectonics of the Aegean region), Geophys. J, R. Astr. Soc., 55, $217-254,1978$.

McKenzle, D., and J. Jackson, The relationship between strain rates, crustal thickening, paleomagnetism, finite strain and fault movements within a deforming zone, Earth Planet. Sci. Lett., 65, 182-202, 1983.

Mercier, J. L., L'Arc Egéen, une bordure déformée de la plaque eurasiatique, reflexions sur un exemple d'étude néotectonique, Bull. Sóc. Géo1. Fr., 19, 663-672, 1977.

Mercier, J, L., M, Delibassis, A. Gauthier, J. J. Jarrige, F. Lemeille, H. Philip, M. Sébrier, and D. Sorẹ1, La néotectonique de 1'Arc Egéen, Rev. Geol. Dyn. Geogr. Phys., 21, 61-72, 1979.

Tapponnier, P., Evolution tectonique du système alpin en Mediterranée: poinçonnement et écrasement rigido-plastique, Bull. Soc. Géol. Fr., 19, 437-460, 1977.

(Received September 10, 1986; revised October 16, 1986.) 